\title{
When My Money Becomes Our Money: Changes in Couples' Money Management
}

\author{
Yvonne Lott
}

Institute of Economic and Social Research, Düsseldorf

E-mail: Yvonne-Lott@boeckler.de

Conservative welfare state policies as in Germany often presume that money is a common resource within couples and, therefore, pooled. Research, however, indicates that money is increasingly managed separately or partly separately. This trend is either explained by the diversification of forms of relationships or interpreted as a general decline of the joint pooling of money. Contributing to this debate, this study investigates whether couples abandon independent money management when particular life events occur or when partners' resources change. Data from the German Socio-Economic Panel (SOEP) for the years 2004, 2005 and 2008 are used. Panel analyses show that marriage leads to joint pooling or partly independent money management. An increase in women's incomes, however, is associated with independent money management. Women's wish for independence apparently contributes to the decline of the joint pool. The substantial prevalence of financial independence within couples calls into doubt the adequacy of German welfare state policies.

Keywords: Family resource management, cohabitation, income, hybrid panel regression models.

\section{Introduction}

Couples manage their money in different ways. Whereas the majority of couples completely organise their finances in a joint pool, a smaller number of couples keep their incomes separate, with independent money management. Some couples pool only part of their incomes and use partly independent money management. Even though the joint pool is still the most widespread money management system in couples, various studies indicate that independent management is becoming increasingly common within intimate relationships (Knudsen and Waerness, 2009; Addabbo et al., 2010; Bennett, 2013). During cohabitation, in particular, independent management is favoured over the use of a joint pool (Vogler et al., 2006; Vogler, 2009). But even in marriages Lauer and Yodanis (2011) observe a slight tendency towards independent management. Two interpretations of this are proposed (Bennett, 2013). On the one hand, separation of finances is seen as a phenomenon primarily related to specific stages in partners' lives and its increase is ascribed to the diversification of family forms (Beck-Gernsheim, 1998). On the other hand, separation of finances is assumed to indicate a long-term decline of the joint pooling system due to the decrease in the prevalence of the male breadwinner model and women's aspiration for financial independence (Stocks et al., 2007). Because joint pooling does not mean joint sharing, but very often women's restricted control of 
and access to resources (Vogler, 2005; Vogler et al., 2006), women seem to prefer the separation of finances over joint pooling. Moreover, even though more and more couples choose to partly separate their incomes, little is known about this money management system.

The present study, therefore, analyses couples who pool their finances and couples who use partly independent money management as opposed to independent money management. The main focus of the analysis is on changes in couples' money management. Do couples change from independent money management to pooling or partly separating their incomes? And, if they do, when do they change their money management system? If the independent system is a life-stage phenomenon specific to particular life stages, couples can be expected to abandon the independent management system in favour of the joint pool or partly independent management at particular times in their lives. Marriage and childbirth are considered to be crucial life events that can be key triggers for changes in money management as they initiate distinct life stages (Bennett, 2013). Furthermore, because the decline of the pooling system is often ascribed to the decline of the male breadwinner model, changes in partners' incomes and employment status are also taken into account. Accordingly, the present study ties in with previous research on marriage and money management systems (e.g., Singh and Lindsay, 1996; Burgoyne et al., 2006; Burgoyne et al., 2007) as well as with studies on the allocation of paid work and income (e.g., Laurie and Gershuny, 2000; Lott, 2009).

The analysis uses data from the German Socio-Economic Panel (SOEP) for the years 2004, 2005 and 2008 ( $N=2,894$ couples and 8,293 couple-years). Germany is a prime example of a conservative welfare state (Esping-Andersen, 2006) whose policies, like those of the UK (Lewis, 1992, 2009a, b), discourage mothers' full-time and fathers' part-time employment (Sainsbury, 1999; Mayer, 2001). Furthermore, the split taxation system, where earned income of one spouse is attributed to the other spouse for the purposes of assessing personal income tax, is a central pillar of the German welfare state. This taxation system treats money as a joint resource in couples and presumes that money is pooled. Analysing money management in Germany, therefore, provides important evidence of whether conservative welfare state policies, notably the split taxation system, are aligned with the lived financial practices in German couples.

This study extends previous research by using nationally representative longitudinal data and applying panel analysis that accounts not only for group differences, but also for time-constant unobservables and couples' self-selection. Cohabiting or childless couples, for instance, might differ from married couples or couples with children in terms of unobserved characteristics with time-constant effects on the choice of money management systems, for example their relationship ideology or partners' personality traits. The estimation of within-unit effects deals with this problem, which may have biased estimations in most previous research on money management. The following section presents recent empirical evidence of changes in money management systems. The article then discusses the role of marriage, childbirth and resources in money management. After describing the data and the empirical strategy, the results are presented. The analysis concludes with a brief overview of the main findings and some reflections on the implications of the study for policymaking. 


\section{Research on money management systems}

In recent decades, much of family researchers' attention has been devoted to the financial resources of couples, especially couples' management of their finances (Vogler and Pahl, 1993; Fleming, 1997; Nyman, 1999; Elizabeth, 2001; Zelizer, 2005; Ashby and Burgoyne, 2008; Miles and Probert, 2009). Research on money management, beginning with Pahl's (1983) study on financial management systems in English households, is essential for an understanding of intra-household inequality, as money management relates to access to household resources, financial decision-making and power (Pahl, 1983, 1989; Vogler and Pahl, 1994). As a result of unequal money management systems, women often have less access to personal spending money, restricted consumption and less power (Burgoyne, 1990; Pahl, 1995; Nyman, 1999).

Furthermore, Vogler (1998) also argues that money management sets the agenda for financial issues decided upon by couples. Money management itself, therefore, can be used to purchase power. The partner who manages the finances has implementing power in the relationship (Safilios-Rothschild, 1976), at least when the household income allows for more than burdensome and time-consuming budgeting to make ends meet and there is money to spare after all the main household expenditures have been covered (Pahl, 1995).

Whereas the joint pool offers the potential for equal sharing, this system does not necessarily mean equal control of, or access to, resources (Vogler et al., 2006: 458). Pooling incomes may allow the myth of equality to be upheld while income discrepancies and unequal gender arrangements are in place (Vogler, 2005: 16). Vogler (2005) and Vogler et al. (2006) found the joint pool to be mostly used in couples with a traditional breadwinner ideology, an unequal allocation of housework and unequal earnings. Earlier research also revealed that, due to the ideology of sharing, women's (self-)restricted access to money and their limited consumption are often concealed (McRae, 1987; Burgoyne, 1990; Nyman, 1999).

The independent management system, by contrast, only provides financial autonomy to individuals who earn enough to make a living on their own. Following the rule of equity (Vogler, 2005), each partner contributes fifty/fifty to the household economy, regardless of the fact that income discrepancies often exist in intimate relationships. As Vogler (2005: 18) emphasises, discrimination occurring in the labour market may be translated into the household and lead to unequal outcomes, mainly for women who encounter greater disadvantages in the labour market.

Most studies have used either qualitative or quantitative cross-sectional data to analyse money management, but few have applied longitudinal designs. Burgoyne et al. (2006) studied money management during the transition to marriage in forty-two heterosexual couples in the South of England with partners mostly born in the 1970s. The partners predominantly stated that they used either the partial or the separate system during the transition period (Burgoyne et al., 2006: 629). In a follow-up study, Burgoyne et al. $(2007,2010)$ found that eight couples stuck to independent management. The majority of couples who changed their management system moved to partial pooling (nineteen couples) and less than half of the couples who changed their system moved to joint pooling (fifteen couples). In their qualitative study of married couples (mostly born in the 1940s and 1950s) and cohabiting couples (mostly born in the 1960s) in Australia, Singh and Lindsay (1996) only observed two couples who got married out of 
fifteen cohabiting couples. These two couples changed to joint pooling after one year of marriage.

To examine management dynamics, some studies have also used retrospective data. Bisdee et al. (2013) analysed money management in forty-five couples, where in the majority of cases the older partner was sixty-five to seventy-five years old. The authors showed that in one group of couples, women had financial independence and power if their partners were in poor health. Earlier experiences of money management systems also affected the way in which they organised their money in later life.

Studying the effect of changes in employment status in a sample broadly representative of the UK in the mid-1980s, Vogler and Pahl (1993) found that when wives start to work or change to full-time employment, partners move from the male-dominated system to the joint pool. It should be noted that their focus was less on independent management than on female- and male-dominated management systems. A more general problem, however, lies in the use of retrospective data, since retrospective responses are often confused with the individual's current situation at the time of the interview.

Recent studies using longitudinal, representative data have analysed changes in couples' satisfaction with their household income using British Household Panel Survey (BHPS) data. Satisfaction with household income is treated as a proxy for access to money in the household. De Henau and Himmelweit (2013) found men's full-time employment to have a more positive influence than women's on both partners' satisfaction with their household income. Furthermore, Bennett et al. (2012) showed that women often make financial choices that have disadvantages for them in the long run - for example, regarding the allocation of resources.

All in all, studies on changes from an independent money management system to joint pooling are rather scarce and do not provide clear empirical evidence, as shown for the non-representative, qualitative studies on marriage, for example Burgoyne et al. (2010) and Singh and Lindsay (1996), where the number of observed marriages was small. There is no evidence available on the effect of childbirth on money management systems. Moreover, most studies on money management were conducted in the 1980s and 1990s and analysed older birth cohorts. These results might therefore not necessarily reflect the actual situation in contemporary societies. Recent research has focused on potential consequences of money management systems (satisfaction with income), but researchers have shown less interest in the use of a partly independent management system. The present study therefore endeavours to fill the gaps in the research.

\section{Marriage, childbirth and partners' resources}

An increasing number of couples use independent management or partly independent systems (Addabbo et al., 2010). For example, Knudsen and Waerness (2009) observed that joint pooling decreased from 29.9 per cent to 23.6 per cent and independent money management increased from 29.7 per cent to around 35.4 per cent in Norwegian couples from 1994 to 2002. Even though this is not a broad change in couples' money management, it is a trend that is becoming more and more apparent in most Western societies (Pahl, 2005). This trend is often explained by the de-institutionalisation of the family (Beck-Gernsheim, 1998; Brückner and Mayer, 2005), which is shown in the increasing numbers of living-apart-together couples, patchwork families and cohabitations. In cohabitations, for example, autonomy is stressed and 'cohabitation 
money' dominates (Elizabeth, 2001: 390). Cohabitation money is highly individualised and kept separate, as shown by various studies (e.g., Vogler, 2005; Vogler et al., 2006). In contrast, the majority of married couples have been found to pool their incomes (Heimdal and Houseknecht, 2003; Lauer and Yodanis, 2011) and organise 'marriage money', which is joint but also nebulous (Singh and Lindsay, 1996). Besides marriage, childbirth is another expression of commitment to the relationship and also makes joint investments necessary. Thus, marriage and childbirth transform the relationship into a 'collective enterprise' (Blumstein and Schwartz, 1983). Following this, it can be expected that these events evoke pooling or at least the partly pooling of money, and that couples abandon independent money management when getting married or having a child.

Another explanation of the decline of joint pooling is seen in the increase in female employment and the decline of the male breadwinner model (Laurie and Gershuny, 2000; Vogler et al., 2008). According to Bennett et al. (2012) and Stocks et al. (2007), women aim to preserve their financial independence in couples and, therefore, favour separate finances. For women, the male breadwinner ideology is declining (Vogler et al., 2006: 465). Men, by contrast, do not attribute their independence to the way their partners organise their finances (Stocks et al., 2007). On the contrary, men still often identify with the role of main breadwinner and, therefore, feel obliged to pool their income. Stocks et al. (2007: 146f) also explain the gendered meanings of money (Pahl, 1989) by examining women's and men's historical positions in couples and societies in general. Whereas men have always been independent and therefore take independence for granted, women have had to struggle against their historical position of 'being economically dependent on others'. They have to actively avoid financial dependence.

Women's urge for independence becomes most obvious in couples where the male breadwinner model is challenged. Women's full-time employment and higher income may, therefore, discourage joint pooling and partly independent management. When women change to full-time employment or their incomes increase, couples may be less likely to abandon complete independent money management and start partly pooling or completely joint pooling.

\section{Method}

Data

Data from the German Socio-Economic Panel are used. ${ }^{1}$ The SOEP is a representative panel study of German households, which started in the Federal Republic of Germany in 1984. In June 1990, following German reunification, the survey was expanded to include the territory of the former German Democratic Republic (Haisken-DeNew and Frick, 2005). Currently, over 12,000 households and 32,000 persons are interviewed every year.

Data from the years 2004, 2005 and 2008 were analysed, as only in these years was money management observed. Because money management is an arrangement implemented by couples, money management is not treated as an individual characteristic of partners, but as a couple characteristic. The sample only includes heterosexual couples where individual information is aggregated to the couple level and couples become the unit of analysis (Kenny et al., 2006). Only those couples were considered where information was available for both partners. The sample was further restricted to couples 
Table 1 Frequency of couples with changes in their money management: getting married, having their first child and experiencing changes in women's and men's employment status in the years 2004, 2005 and 2008

\begin{tabular}{lr}
\hline \hline & $\mathrm{N}$ \\
\hline $\begin{array}{l}\text { From independent management to } \\
\quad \text { joint pooling }\end{array}$ & 132 \\
$\quad$ partly independent management & 92 \\
$\begin{array}{l}\text { From cohabitation to } \\
\quad \text { marriage }\end{array}$ & 172 \\
$\begin{array}{l}\text { From no child to } \\
\quad \text { first child }\end{array}$ & 84 \\
$\begin{array}{l}\text { From women's part-time/minor employment/not working to } \\
\quad \text { full-time employment }\end{array}$ & 341 \\
$\begin{array}{l}\text { From men's part-time/minor employment/not working to } \\
\quad \text { full-time employment }\end{array}$ & 290 \\
\hline \hline
\end{tabular}

Note: 2,894 couples and 8,293 couple-years.

Source: author's analysis; SOEP (2004, 2005 and 2008).

with the oldest partner younger than sixty-six years (the legal age of retirement in Germany). ${ }^{2}$

The initial sample included 11,721 couple-years. i.e. the aggregated number of couples observed in 2004, 2005 and 2008. Money management, however, was missing for 1,659 couple-years, men's share of childcare was missing for 1,100 couple-years, women's income was missing for 678 couple-years and men's share of housework was not available for 636 couple-years. The resulting sample for the analysis comprises 8,293 couple-years $(2,777$ couples in 2004, 2,911 in 2005, and 2,605 in 2008). It should be noted that this sample and the initial sample do not differ significantly in relevant characteristics to couples used in the analysis.

Of the total sample, 1,868 couples were observed for all three years. This represents 67.58 per cent of the total sample; 24.74 per cent were observed in two years, and 7.68 per cent were observed only in one year. For the latter, changes in money management could not be estimated. The group of couples with two observed years might comprise couples who split up during the observation period. The analysis therefore controlled for whether couples were observed for the whole observation period. Moreover, one or both partners of a newly formed couple might have already been observed in former relationships in the sample. In this case, the 'old' and the 'new' couples are treated as independent observations.

In the sample, 132 couples changed from independent management to joint pooling and ninety-two couples from independent to partly independent management (Table 1); 172 couples married, and eighty-four became parents. Women changed from parttime or minor employment to full-time employment in 341 couples and men did so in 290 couples. The average within-deviation of income from the unit-specific mean is $€ 6,183.54$ for women and $€ 10,492.80$ for men. It should be noted that the majority of couples stay with the money management system they already used before the life 
events took place. Nevertheless, almost a third of the couples getting married within the observation period (fifty-seven couples) and almost half of the couples having their first child (thirty-seven couples) change their management system. When women change to full-time employment, more than a quarter (ninety-eight couples) change their money management.

\section{Outcome variable: money management}

Money management systems were observed in 2004, 2005 and 2008 with the survey question: 'How do you and your partner (or spouse) manage the income that one or both of you receive?' Responses included $1=$ separate, $2=I$ do it, $3=$ partner does it, $4=$ pool and $5=$ partly separate. Because the focus of this study is on changes from independent to partly independent management systems and joint pooling, the outcome variables in the regression analysis are coded with $0=$ independent management system and $1=$ joint pool and with $0=$ independent management system and $1=$ partly independent management. Changes from independent management to only one partner management were rare (nineteen couples changed to 'I do it' and sixteen couples to the 'partner does $i^{\prime}$ ). Due to the low number of cases for these categories, these were not considered in the analysis. It should be noted that individuals are not asked about a specific practice (for example, organising bank accounts), but about managing their incomes in general. This might be a reason for differences in partners' responses in approximately 6 per cent of the observed couples. In order to account for these differences, one response was randomly chosen and the analysis controlled for whether partners gave the same answers.

\section{Explanatory variables}

The explanatory variables used in the analysis are marital status, childbirth, partners' full-time position and incomes. (Table 2 presents all variables of the analysis.) Marital status was coded with $0=$ cohabiting and $1=$ married. Children were measured as $0=$ no children and $1=$ one or more children. For this latter variable, the transition to first parenthood was primarily observed in the data. The majority of couples experienced the birth of their first child and just two couples experienced the birth of twins within the observation period. Dummy variables measured $0=$ part-time, minor employment or not working and $1=$ full-time employment for each partner. The partners' personal annual net labour market income ${ }^{3}$ (log-transformed) was used as an income measure. Because money has social meaning, social benefit payment might be valued less than labour income. The variable was therefore restricted to a measure of labour market income alone. In order to test the assumption that the rise in independent money management is related to the decline of the breadwinner model, a differentiation is made between women's and men's resources and employment status. The differentiation between female and male partners' characteristics is also applied to the control variables.

\section{Controls}

Previous research showed that the total amount of money to be managed plays a crucial role in money management systems (Vogler and Pahl, 1993). The higher the household income, the more likely couples are to separate their finances (Lott, 2009). It was therefore 
Table 2 Descriptive statistics ( $N=8,293$ couple-years; years 2004, 2005 and 2008)

\begin{tabular}{|c|c|c|c|c|}
\hline Variables & Mean/share & SD & Min & Max \\
\hline \multicolumn{3}{|l|}{ Money management system } & 1 & 3 \\
\hline joint pool & $15 \%$ & & & \\
\hline partly independent system & $75 \%$ & & & \\
\hline independent system & $10 \%$ & & & \\
\hline \multicolumn{3}{|l|}{ Marital status } & 0 & 1 \\
\hline married & $87 \%$ & & & \\
\hline cohabiting & $13 \%$ & & & \\
\hline \multicolumn{3}{|l|}{ Children } & 0 & 1 \\
\hline no child & $64 \%$ & & & \\
\hline one or more children & $36 \%$ & & & \\
\hline \multicolumn{3}{|l|}{ Women's employment status } & 1 & 3 \\
\hline full-time & $33 \%$ & & & \\
\hline part-time/minor employment & $45 \%$ & & & \\
\hline not working & $21 \%$ & & & \\
\hline \multicolumn{3}{|l|}{ Men's employment status } & 1 & 3 \\
\hline full-time & $79 \%$ & & & \\
\hline part-time/minor employment & $13 \%$ & & & \\
\hline not working & $8 \%$ & & & \\
\hline Women's income (log.) & 6.95 & 5.57 & -4.61 & 12.79 \\
\hline Men's income (log.) & 9.43 & 3.78 & -4.61 & 13.08 \\
\hline Joint incomes in couples (in Euro) & $56,775.58$ & $37,295.24$ & 50 & 480,000 \\
\hline Women's share of joint incomes & $32 \%$ & $28.33 \%$ & $0 \%$ & $100 \%$ \\
\hline Household income & $25,833.04$ & $64,972.33$ & $1,299.46$ & $4,053,006$ \\
\hline Men's share of housework & $22 \%$ & $23.20 \%$ & $0 \%$ & $100 \%$ \\
\hline Men's share of childcare & $11 \%$ & $20.20 \%$ & $0 \%$ & $100 \%$ \\
\hline Women's education (in years) & 12.30 & 3.11 & 0 & 18 \\
\hline Men's education (in years) & 12.61 & 3.07 & 0 & 18 \\
\hline Women's previous divorce & $3 \%$ & & 0 & 1 \\
\hline Men's previous divorce & $3 \%$ & & 0 & 1 \\
\hline Duration of relationship (in years) & 18.43 & 11.09 & 0 & 47 \\
\hline Youngest child one to three years & $8 \%$ & & 0 & 1 \\
\hline Youngest child four to five years & $6 \%$ & & 0 & 1 \\
\hline Youngest child six to eleven years & $16 \%$ & & & \\
\hline Youngest child twelve to fifteen years & $10 \%$ & & & \\
\hline Women's age (in years) & 43.74 & 9.85 & 19 & 65 \\
\hline Men's age (in years) & 46.28 & 10.05 & 20 & 65 \\
\hline \multicolumn{3}{|c|}{ Partners' responses on money management } & 0 & 1 \\
\hline Same responses & $94 \%$ & & & \\
\hline Contradicting responses & $6 \%$ & & & \\
\hline Observed in all years & $67 \%$ & & 0 & 1 \\
\hline
\end{tabular}

Note: Women's income, men's income and household income not adjusted for inflation; 2,894 couples and 8,293 couple-years.

Source: author's analysis; SOEP (2004, 2005 and 2008).

necessary to control for the household income. ${ }^{3}$ The household income is the total family income from labour earnings, asset flows, private retirement income, private transfers, public transfers and social security pensions, minus total family taxes. The annual net household income was equivalence-scaled for children aged fourteen or younger using the 
modified OECD scale and integrated as a continuous variable in the models. Furthermore, Vogler et al. (2006: 462) found that money management is interrelated with the division of housework and childcare. It was therefore controlled for these gender arrangements. Two variables were used that measure men's proportion of the sum of both partners' time investment (measured in hours per weekday) in household tasks and childcare, respectively. Partners' educational levels may also be crucial for money management in couples. Men's and women's years of education were introduced as continuous variables in the regression models. In addition, money management systems may depend on the age of the youngest children in the household. The analysis therefore controlled for whether the youngest child was in the age range of one to three years, four to five years, six to eleven years or twelve to fifteen years.

The focus of this study is on changes in money management systems triggered by events. However, gender arrangements may also change during the course of the relationship. In order to disentangle the effects of events and duration, the duration of the relationship was introduced into the models. For married couples, it was possible to use retrospective data on the duration of the relationship. The maximum value for the duration of the relationship is therefore forty-seven years. For cohabiting couples retrospective information is not available in the SOEP, so the variable had to be generated from the observed duration in the SOEP data from 1984 to 2008. Note that the sample includes leftcensored cases for those couples who were already cohabiting before entering the panel study. Relationship duration was used as a continuous variable. Because individuals who have already experienced divorces often avoid pooling money in their new relationship (Heimdal and Houseknecht, 2003), two dummy variables were also used to measure whether the man or woman had experienced a divorce in the past. Furthermore, the analysis controlled for women's and men's ages. Finally, a period dummy variable was integrated into the models, where 2004 and 2005 were combined and coded 0 and 2008 was coded 1.

\section{Analysis}

To examine the consequences of changes within couples on money management, within-unit estimates are most appropriate. Between-unit differences may provide further important insights about the characterstics of money management systems. Therefore, hybrid panel regression models were estimated. ${ }^{4}$ Hybrid panel regression allows for the estimation of differences within groups and, at the same time, between groups (Schunck, 2013: 66). The hybrid model is based on a random effects panel regression model. Variables are included in two forms: as unit-specific, time-constant means (between-estimates), and as the time-variant deviation from the unit-specific means (within-estimates) (Allison, 2009). In the present study, the between-estimates indicate differences between couples; the within-estimates are the effects of within-couple change over time. The between-estimate of marital status, for example, describes the differences in the chances of pooling money for married couples compared to cohabiting couples. The within-estimate of marital status describes the differences in the chances that a couple changes from independent management to joint pooling when changing from cohabitation to marriage. The within-unit estimates are a measure of change within specific couples over time and are identical to estimates obtained in a fixed-effects panel regression model. For estimating the within-unit effect, only those couples are considered 
for whom a change in a specific characteristic has been observed, for example those who got married within the observation period. Those couples who remained cohabiting are excluded from the estimation of the effect.

The advantage of within-unit estimates is that they account for unobserved timeconstant heterogeneity, such as personality traits of partners in the couple (Allison, 2009). The bias due to selection on time-constant characteristics can be reduced in this way. In the hybrid model, however, the between-estimates are still confounded with unobserved time-constant heterogeneity. For example, married couples may be more willing to commit themselves to, and to invest in, relationships than non-married couples. In married couples, therefore, sharing money between partners may be more common compared to non-married couples.

Because the estimation of a multinomial logistic hybrid model is computationally too extensive, two binary logistic hybrid models were estimated for the dependent variables with $0=$ independent management and $1=$ joint pool and partly independent management, respectively. Before discussing the results of the hybrid panel regression models, a descriptive analysis will give insights into the association of money management with marital status, children, employment status and income and money management (Table 3).

\section{Results}

Descriptive analysis

Table 2 describes the variables used in the analysis. The mean values point to a rather unequal allocation of paid and unpaid work in couples. In 2004, 2005 and 2008, men, on average, perform 22 per cent of the housework and 11 per cent of childcare, which leaves women with an average share of 78 per cent of the housework and 89 per cent of childcare. Moreover, women's mean income is less than half of men's mean income. They earn only an average share of the joint income of 32 per cent. Women predominantly have part-time or minor employment, and only one third have full-time positions, while their partners mostly work full-time. Men's and women's education is similar, however, with a mean of twelve years. Equality in education does not necessarily translate into an equal allocation of paid work. As for couples' characteristics, the majority of couples are married and more than half of the couples in the sample have at least one child. The median duration of the relationship is twenty-one years. The average age for women is forty-three years and for men it is forty-six.

The majority of couples use joint pooling (Table 3). Almost 76 per cent of the couples report pooling of incomes. Only 15 per cent say that they manage their finances separately, and about 9 per cent of couples use partly independent management. The majority of cohabiting couples (48 per cent) use independent management and another 20 per cent separate their incomes partly. In married couples, by contrast, joint pooling predominates with approximately 83 per cent. This finding supports previous studies which found that cohabiting couples mainly organise their finances separately (Vogler et al., 2006; Vogler, 2009). The differences between married and cohabiting couples are highly significant. The partly independent system also seems to be popular among cohabiting couples. These results do not yet provide evidence of changes in money management systems, which will be examined in the multivariate analysis. 
Table 3 Money management systems and couples' characteristics and arrangements

\begin{tabular}{|c|c|c|c|c|}
\hline In \% (mean for income) & $\begin{array}{l}\text { Independent } \\
\text { management } \\
\text { system }\end{array}$ & $\begin{array}{l}\text { Pooled } \\
\text { management }\end{array}$ & $\begin{array}{l}\text { Partly } \\
\text { independent } \\
\text { management }\end{array}$ & $\mathrm{N}$ \\
\hline General & 15.07 & 76.19 & 8.74 & 8,293 \\
\hline \multicolumn{5}{|l|}{ Relationship status } \\
\hline cohabiting & 48.35 & 31.51 & 20.14 & 1,050 \\
\hline married & 10.24 & 82.67 & 7.09 & 7,243 \\
\hline chi $^{2}$-test ${ }^{(\mathrm{a})}$ & & $* * *$ & $* * *$ & \\
\hline \multicolumn{5}{|l|}{ Children } \\
\hline no children & 22.21 & 66.80 & 11.00 & 2,986 \\
\hline child(ren) & 10.80 & 81.79 & 7.40 & 5,307 \\
\hline chi $^{2}$-test ${ }^{(a)}$ & & *** & ** & \\
\hline \multicolumn{5}{|l|}{ Women's employment status } \\
\hline full-time & 25.00 & 63.67 & 11.32 & 2,709 \\
\hline $\begin{array}{l}\text { part-time/minor employment/not } \\
\text { working }\end{array}$ & 11.04 & 81.26 & 7.70 & 5,584 \\
\hline chi $^{2}$-test ${ }^{\text {(a) }}$ & & *** & *** & \\
\hline \multicolumn{5}{|l|}{ Men's employment status } \\
\hline full-time & 15.89 & 75.35 & 8.77 & 6,576 \\
\hline $\begin{array}{l}\text { part-time/minor employment/not } \\
\text { working }\end{array}$ & 12.09 & 79.25 & 8.66 & 1,717 \\
\hline chi $^{2}$-test ${ }^{(\mathrm{a})}$ & & ** & n.s. & \\
\hline $\begin{array}{l}\text { Women's mean income (log.) } \\
\text { t-test }{ }^{(\mathrm{b})}\end{array}$ & $21,888.67$ & $\underset{* * *}{12,963.38}$ & $\begin{array}{l}18,797.18 \\
* * *\end{array}$ & 8,293 \\
\hline $\begin{array}{l}\text { Men's mean income (log.) } \\
\text { t-test }\end{array}$ & $37,277.86$ & $\begin{array}{l}34,748.83 \\
\text { n.s. }\end{array}$ & $\begin{array}{l}35,683.4 \\
\text { n.s. }\end{array}$ & 8,293 \\
\hline
\end{tabular}

Notes: (a) Pearson chi squared is estimated for cross tables comparing couple characteristics and the frequency of independent management versus joint pool and independent management versus partly independent management. (b) Two-sample t-tests compare mean values of income for couples with independent management versus joint pool and couples with independent management versus partly independent management; percentages weighted with cross-sectional weight; Pearson chi squared and two sample t-test compare values.

${ }^{*} \mathrm{p}<0.05^{* *} \mathrm{p}<0.01{ }^{* * *} \mathrm{p}<0.001$

Source: author's analysis; SOEP (2004, 2005 and 2008).

Couples without children separate their earnings more often than couples with children (Table 3). While around 22 per cent of childless couples use the independent management system, less than 11 per cent of couples with children report organising their finances separately. Differences for partly independent management are much smaller and less significant than for joint pooling. Eleven per cent of couples without children and approximately 7 per cent of couples with children use this system. Moreover, results for the allocation of paid work and income support previous studies (Vogler, 2005; Lott, 2009). The independent management system is more often used when women work full-time. Differences in employment status are highly significant. Twenty-five per cent of couples with women in full-time employment separate their finances, but only 11 per cent of couples with women in part-time work, minor employment or not working keep incomes separate. In these couples, joint pooling predominates at 81 per cent. 
Again, group differences for the partly independent system are smaller but statistically significant.

While women's employment status seems to make a difference for couples' money management, money management does not differ according to men's employment status. Men's employment status is less significantly associated with joint pooling and is not significant for partly independent management. Women's employment status seems to matter more for the way couples manage their finances. A similar tendency can be observed for income. In couples with the independent system, women's income is almost twice as high as in couples that pool their finances. These differences in mean income are highly significant. Men's mean incomes do not differ significantly between management systems.

Overall, unlike independent management, the partly independent system does not show a clear pattern of couple-specific characteristics. Only marriage and women's higher income are clearly related to partly independent management. Married couples and couples in which women have a higher income use the partial system more often. Furthermore, women's full-time employment status and higher income is positively associated with independent management, while the joint pool is more often used in couples with a traditional allocation of resources. When women have an employment status other than full-time or do not work at all and when their income is low, couples are more likely to use the joint pool. The descriptive analysis confirms previous findings (Vogler, 2005; Lott, 2009). Whether these results are confirmed in the multivariate analysis is examined in the following section.

\section{Multivariate analysis}

Table 4 shows the results of the hybrid panel regression models for the explanatory variables. ${ }^{5}$ With the between-estimates, couples are compared to other couples, for example married couples with cohabiting couples. In contrast, the within-estimates measure changes within the same couple over time, for example the time before a couple got married is compared to the time as a married couple.

The between-estimates are discussed first. Married couples are more likely than cohabiting couples to jointly pool than separate their incomes. It should be noted that the effect size of being married as opposed to cohabiting is high (760.277) and highly significant. This is due to the low variation in money management in married couples. Ninety-three per cent of the observed respondents who are married pool their incomes. This strong correlation, however, does not bias the other estimates in the model. When excluding 'married' and 'getting married' from the regression model, coefficients of the other variables do not change substantially. Being married as opposed to cohabiting is also significantly related to partly independent management. The chances that married couples partly rather than completely separate their finances is more than four times greater (4.760) compared to cohabiting couples. In addition, the chances of joint pooling are higher in couples with children compared to childless couples. The chances that couples with children use joint pooling instead of independent management is more than three times greater (3.524) compared to childless couples. Children, however, are not significantly associated with partly independent management.

Furthermore, results point to the relation between a weakened male breadwinner model and independent management. Couples where women work full-time are less 
Table 4 Random-effects models with comparisons between couples and changes within couples for the joint pool and partly independent management for the overall sample, odds ratios and standard errors presented

\begin{tabular}{|c|c|c|c|c|}
\hline \multirow[b]{2}{*}{ Ref. Independent management } & \multicolumn{2}{|c|}{$\begin{array}{l}\text { Pooled management } \\
\text { Model } 1\end{array}$} & \multicolumn{2}{|c|}{$\begin{array}{l}\text { Partly independent } \\
\text { management } \\
\text { Model } 2\end{array}$} \\
\hline & Odds ratio & Std. error & Odds ratio & Std. error \\
\hline \multicolumn{5}{|l|}{ Comparison between couples (between estimates) } \\
\hline Married (ref. cohabiting) & $760.277^{* * *}$ & $(373.18)$ & $4.760^{* * *}$ & $(1.74)$ \\
\hline Children (ref. no child) & $3.524^{* * *}$ & $(1.26)$ & 1.643 & $(0.59)$ \\
\hline Women full-time employed (ref. part-time, minor employment, not working) & $0.231^{* * *}$ & $(0.07)$ & $0.544^{*}$ & $(0.17)$ \\
\hline Men full-time employed (ref. part-time, minor employment, not working) & 0.465 & $(0.22)$ & 0.630 & $(0.26)$ \\
\hline Women's income (log.) & $0.832^{* * *}$ & $(0.03)$ & 0.975 & $(0.03)$ \\
\hline Men's income (log.) & 0.984 & $(0.05)$ & 1.076 & $(0.05)$ \\
\hline Women & $0.594^{*}$ & $(0.14)$ & 0.996 & $(0.21)$ \\
\hline Same responses given be partners (ref. contradictory responses) & $236.246^{* * *}$ & $(140.69)$ & $0.233^{* * *}$ & $(0.10)$ \\
\hline \multicolumn{5}{|l|}{ Change within couples (within effects) } \\
\hline Getting married & $7.048^{* * *}$ & $(4.16)$ & 2.134 & $(1.12)$ \\
\hline Having the first child & 1.883 & $(0.86)$ & 0.956 & $(0.52)$ \\
\hline Women change from part-time, minor employment, not working to full-time & 0.927 & $(0.26)$ & 0.860 & $(0.27)$ \\
\hline Men change from part-time, minor employment, not working to full-time & 0.745 & $(0.25)$ & 0.898 & $(0.34)$ \\
\hline Women's income increases & $0.894^{* * *}$ & $(0.03)$ & $0.932 *$ & $(0.03)$ \\
\hline Men's income increases & 0.970 & $(0.04)$ & 0.958 & $(0.05)$ \\
\hline Changing from contradictor responses to same responses & $1.902 *$ & $(0.58)$ & $0.195^{* * *}$ & $(0.05)$ \\
\hline Constant & 0.436 & $(0.99)$ & 25.738 & $(53.45)$ \\
\hline
\end{tabular}


Table 4 Continued

\begin{tabular}{|c|c|c|c|c|}
\hline \multirow[b]{2}{*}{ Ref. Independent management } & \multicolumn{2}{|c|}{$\begin{array}{l}\text { Pooled management } \\
\text { Model } 1\end{array}$} & \multicolumn{2}{|c|}{$\begin{array}{l}\text { Partly independent } \\
\text { management } \\
\text { Model } 2\end{array}$} \\
\hline & Odds ratio & Std. error & Odds ratio & Std. error \\
\hline \multicolumn{5}{|l|}{ Insig2u } \\
\hline Constant & $20.527^{* * *}$ & $(1.85)$ & $5.850^{* * *}$ & $(1.04)$ \\
\hline Log likelihood & & -19.672 .141 & & -11.489 .459 \\
\hline Number of observations & & 7,531 & & 2,032 \\
\hline Number of couples & & 3,385 & & 1,112 \\
\hline
\end{tabular}

Notes: Random-effects models with between- and within-estimates; odds ratio and standard errors. Model 1: dependent variable (0) independent management and (1) joint pool; Model 2 dependent variable (0) independent management and (1) partly independent management. Additionally models include the control variables men's education, women's education, men's share of housework, men's share of childcare, duration of the relationship, household income, men's former divorce, women's former divorce, men's age and age squared, women's age and age squared, age of the youngest child (four dummy variables), year and observed in all years.

${ }^{*} p<0.05^{* *} p<0.01{ }^{* * *} p<0.001$.

Source: author's analysis; SOEP (2004, 2005 and 2008). 
likely by a factor of 0.231 to use the joint pool compared to independent management than are couples where women have a lower or no employment status. This coefficient is highly significant. Couples are also less likely by a factor of 0.544 to use the partly independent management system. Women's logged income is also negatively and significantly associated with the joint pool. When women have a higher income, couples are less likely by a factor of 0.832 to pool their incomes than to separate their finances. By contrast, men's incomes and employment status do not affect the way couples manage their finances.

We now turn to the within-estimates. From these estimates we can see how couples change their money management when they get married, become parents or change their allocation of resources and paid work. The within-estimates reveal that couples who become parents and couples in which women start to work full-time do not change their management system significantly. This is in contrast to the between-estimates and may indicate that unobserved characteristics of couples bias the between-estimates for children and women's full-time employment. Couples who have decided to have children might be more willing overall to make common investments than couples without children. Couples where women are in part-time or minor employment might view the relationship as a collective enterprise where women have the opportunity to rely on their partners' income. Couples where women are in full-time employment, by contrast, might stress each partner's autonomy more.

The within-estimates for getting married and the increase in women's income, however, are statistically significant. The chances that couples stop separating their finances and start using the joint pool are more than seven times higher when getting married (7.048). Moreover, the increase in women's income has a significant negative impact on the chances of joint pooling and partly separating finances. The chances for the joint pool are reduced by a factor of 0.894 and for partly independent management by a factor of 0.932 compared to independent management when women's annual logged income increases by 1 point. These effects are considerable in size and highly significant. Couples are less likely to start, and more likely to stop pooling money or partly pooling money, when women receive a higher income, even when accounting for time-constant unobservables.

With regard to the control variables, two observations can be made. First, gender is significantly related to pooling money. Women are less likely than men to report joint pooling. This supports the assumption that women stress autonomy more than men, at least they claim more often to separate their finances. In order to further explore the differences between men and women, the models were estimated for women and men separately. Even though the effects of the explanatory variables point in a similar direction as those obtained from the general analysis (women's urge for financial independence, men highlighting jointness), they are not significantly different between the models. ${ }^{6}$ Second, in order to account for differences in partners' perceptions, the models included a control for couples' response behaviour. The between-effects as well as the within-effects are significantly associated with joint pooling and partly separating money, and the effects are large. Couples in which both partners give the same answer are more likely to report joint pooling (236.246) and are less likely to report partly independent management (0.233) than independent management. The effect size of same responses is high in the model for joint management due to the low variation in money management in couples 
whose partners agree upon their management system. Again, this strong correlation does not affect the other estimates in the model.

Also, change to same responses is associated with starting to pool money, whereas it is less likely that couples abandon independent management in favour of partly independent management. Thus, joint management is highly associated with partner's agreement about their management system. Couples, however, do not always seem to have the same idea about what partly independent management really is. Not only does the partly independent management lack a clear pattern of couple characteristics, but partners' perceptions of partly separating money also tend to be contradictory.

\section{Discussion}

The main goal of the study was to scrutinise how life events and changes in the allocation of resources and paid work are associated with changes in couples' money management. When do couples switch from independent management to more pooled forms of money management? The study has shown that, although the majority of couples stick to their management system, a considerable number of couples change the way they organise money throughout the life course. Marriage is a crucial life event that is likely to transform money into 'marriage money'. Almost one third of the couples who got married within the observation period changed their management system, and couples who get married are more likely to start pooling money than stay with independent management. Childbirth, by contrast, does not impact on couples' management system significantly.

The study also indicates that independent money management runs parallel to the decline of the male breadwinner model and the growth in female employment. Panel analysis revealed that the increase in women's income has a strong effect on their money management system. Couples are less likely to switch to completely or partly pooling money when women's income increases. Pooling money remains strongly related to traditional gender asymmetry in couples, but when women have sufficient financial resources, couples more often use the independent management system. Even though pooling money or, at least, partly pooling, has the potential to compensate for financial disadvantages, gender inequality is often reproduced and hidden by the joint pool. Women seem to avoid this inequality in relationships, when they can afford it. The study further revealed that the partly independent management system is less an expression of the 'collective' enterprise than the joint pool. This form of money management is not related to distinct characteristics of couples, and partners do not agree about what partly separating money actually is.

It should be noted that very few within-estimates are significant. Within the short observation period of four years, many couples did not change their management system, and life events such as marriage and childbirth did not occur very often. Moreover, longterm effects of events on couples' money management, and the differences between those couples who stay together and those who split up should be analysed, which was not possible with the data. This also calls for richer data in order to investigate differences between couples who split up and those who stay together. In addition, the present analysis was unable to reveal which management system is actually used in couples where partners gave contradictory answers that indicate systematic gender differences. Even though this applies to only about 6 per cent of the observed couples, partners' response behaviour plays a crucial role for the management system. Existing qualitative 
research (e.g., Burgoyne et al., 2006; Stocks et al., 2007) should be extended in order to further reveal the meaning of money in couples and its role for relationship ideologies. This might be especially interesting for couples that use mixed forms of money management, such as partly independent management, and where partners do not necessarily agree upon how to deal with financial issues. Extending existing surveys by adding questions on financial organisation that are more specific in order to differentiate between relationship ideology and money management practices is another solution to this problem.

Finally, cross-country comparisons are necessary to further reveal the role of state welfare policies for couples' money management. Even though Germany is, like the UK, a 'laggard' (Lewis, 2009a: 445) when it comes to public childcare and German and British mothers mainly working in part-time positions (OECD, 2013), both countries differ in their taxation system. With the split taxation system that is in place in Germany, the income of one spouse is attributed to the other spouse for the purpose of assessing personal income tax. One problem of this taxation system is that it favours couples with the traditional allocation of incomes and therefore discourages women's re-entry into full-time employment leading to high gender pay gaps within couples (Sainsbury, 1999). Another problem is that the split taxation system assumes that incomes are jointly managed in the household. As a result, couples may respond to the legal default of jointness by organising their incomes jointly, even though some partners (most probably women) may actually prefer independent management. A comparison between the UK and Germany would allow evaluation of the role of the taxation system in couples' money management. Moreover, a cross-country comparison of changes over time of money management would also reveal the influence of the recent financial crisis on the way that couples manage money. Germany was hit less hard by the recession compared to the UK or the US. In the latter countries, the financial crisis might evoke partners' sharing money in order to protect each other financially.

Disregarding these limitations, the study showed that women's higher incomes discourage joint pooling. Women seem to prefer financial autonomy if they have the necessary resources. The results question the adequacy of conservative welfare state policies. This is especially the case for the split taxation system, which suggests that income is joint and thus does not reflect the reality of couples who wish to separate their finances or already do so. Women's urge for financial autonomy might be especially pressing in countries where within-couples inequalities are rather high. This urge might therefore not only be a German phenomenon, but might also apply to other welfare states with similarly strong support for the male breadwinner model.

\section{Acknowledgments}

I would like to express my thanks to the three reviewers, whose very helpful comments greatly improved the article. I also would like to thank Philipp Lersch for his advice on previous versions of this article.

\section{Notes}

1 http://www.diw.de/soep.

2 Labour income and pension payments might differ in their social meanings (Zelizer, 1994). Income that is earned on top of pension payments might be less important for individuals than income that is their 
main financial resource. In addition, retired individuals and individuals of working age might differ with regard to their reasons for being employed. In order to avoid biased estimates for employment and income, only couples where both partners are of working age were considered.

3 The individual income and the household income were not adjusted for inflation because of the relatively short observation period.

4 Three-level multilevel models were also estimated to account for non-independence over time within partners within couples. Due to insufficient variation within partners, the random-effects parameters at this level could not be estimated. Instead, one partner from each couple was randomly selected and two-level random-effects models were therefore estimated in the form of hybrid panel regression models.

5 In order to facilitate the interpretation of the results, the complete regression models are not shown. The complete regression table is available from the author.

6 The data for gender differences is not shown, but available from the author.

\section{References}

Addabbo, T., Arrizabalaga, M.-P., Boderías, C. and Owens, A. (2010) 'Introduction: households, gender and the production of well-being', in T. Addabbo (ed.), Gender Inequalities, Households and the Production of Well-Being in Modern Europe, Burlington, VT: Ashgate, pp. 3-24.

Allison, P. D. (2009) Fixed Effects Regression, Thousand Oaks, CA: Sage.

Ashby, K. J. and Burgoyne, C. B. (2008) 'Separate financial entities? Beyond categories of money management', The Journal of Socio-Economics, 37, 2, 458-80.

Beck-Gernsheim, E. (1998) Was kommt nach der Familie?: alte Leitbilder und neue Lebensformen, Munich: Beck.

Bennett, F. (2013) 'Researching within-household distribution: overview, developments, debates, and methodological challenges', Journal of Marriage and Family, 75, 3, 582-97.

Bennett, F., De Henau, J., Himmelweit, S. and Sung, S. (2012) 'Financial togetherness and autonomy within couples', in J. Scott, S. Dex and A. C. Plagnol (eds.), Gendered Lives: Gender Inequalities in Production and Reproduction, Cheltenham: Edward Elgar, pp. 97-122.

Bisdee, D., Daly, T. and Price, D. (2013) 'Behind closed doors: older couples and the gendered management of household money', Social Policy and Society, 12, 1, 163-74.

Blumstein, P. and Schwartz, P. (1983) 'Money and ideology: their impact on power and the division of household labor', in R. L. Blumberg (ed.), Gender, Family and Economy: The Triple Overlap, London: Sage, pp. 261-88.

Brückner, H. and Mayer, K. U. (2005) 'De-standardization of the life-course: what it might mean? And if it means anything, whether it actually took place?', Advances in Life Course Research, 9, 27-53.

Burgoyne, C. B. (1990) 'Money in marriage: how patterns of allocation both reflect and conceal power', The Sociological Review, 38, 4, 634-65.

Burgoyne, C. B., Clarke, V., Reibstein, J. and Edmunds, A. (2006), '“All my worldly goods I share with you"? Managing money at the transition to heterosexual marriage', The Sociological Review, 54, 4, 619-37.

Burgoyne, C. B., Reibstein, J., Edmunds, A. and Dolman, V. (2007) 'Money management systems in early marriage: factors influencing change and stability', Journal of Economic Psychology, 28, 2, 214-28.

Burgoyne, C. B., Reibstein, J., Edmunds, A. M. and Routh, D. A. (2010) 'Marital commitment, money and marriage preparation: what changes after the wedding', Journal of Community and Applied Psychology, 20, 5, 390-403.

De Henau, J. and Himmelweit, S. (2013) 'Unpacking within-household gender differences in partners' subjective benefits from household income', Journal for Marriage and Family, 75, 3, 611-24.

Elizabeth, V. (2001) 'Managing money, managing coupledom: a critical examination of cohabitants' money management practices', The Sociological Review, 49, 3, 389-411.

Esping-Andersen, G. (2006) 'Three Worlds of Welfare Capitalism', in C. Pierson and F. G. Castles (eds.), The Welfare State Reader, Cambridge: Polity Press, pp. 160-73. 
Fleming, R. (1997) The Common Purse: Income Sharing in New Zealand Families, Auckland: Auckland University Press.

Haisken-DeNew, J. P. and Frick, J. (2005) Desktop Companion to the German Socio-Economic Panel $(S O E P)$, Berlin: DIW Berlin.

Heimdal, K. and Houseknecht, S. (2003) 'Cohabiting and married couples' income organization: approaches in Sweden and the United States', Journal of Marriage and Family, 65, 3, 525-38.

Kenny, D. A., Kashy, D. A. and Cook, W. L. (2006) Dyadic Data Analysis, New York: Guilford Press.

Knudsen, K. and Waerness, K. (2009) 'Shared or separate? Money management and changing norms of gender equality among Norwegian couples', Community, Work and Family, 12, 1, 39-55.

Lauer, S. R. and Yodanis, C. (2011) 'Individualized marriage and the integration of resources', Journal of Marriage and Family, 73, 3, 669-83.

Laurie, H. and Gershuny, J. (2000) 'Couples, work and money', in J. Gershuny and R. Berthoud (eds.), Seven Years in the Lives of British Families: Evidence on the Dynamics of Social Change from the British Household Panel Survey, Bristol: Policy Press, pp. 45-72.

Lewis, J. (1992) 'Gender and the development of welfare regimes', Journal of European Social Policy, 2, 3, 159-73.

Lewis, J. (2009a) 'Balancing "time to work" and "time to care": policy issues and the implications for mothers, fathers and children', Child and Family Law Quarterly, 21, 4, 443-61.

Lewis, J. (2009b) Work-Family Balance, Gender and Policy, Cheltenham: Edward Elgar.

Lott, Y. (2009) 'Verwaltung und Entscheidung - Bestimmt das individuelle Einkommen die Machtverteilung in Paarbeziehungen?', Kölner Zeitschrift für Soziologie und Sozialpsychologie, 61, 3, 327-53.

Mayer, K. U. (2001) 'The paradox of global social change and national path dependencies', in A. Woodward and M. Kohli (eds.), Inclusion and Exclusion in European Societies, London and New York: Routledge, pp. 89-110.

McRae, S. (1987) 'The allocation of money in cross-class families', The Sociological Review, 35, 1, 97-122. Miles, J. and Probert, R. (2009) Sharing Lives, Dividing Assets: An Inter-Disciplinary Study, Oxford: Hart.

Nyman, C. (1999) 'Gender equality in the most equal country in the world? Money and marriage in Sweden', The Sociological Review, 47, 4, 766-93.

OECD (2013) OECD Labour Force Statistics 2013, Paris: OECD, http://dx.doi.org/10.1787/oecd_ifs-2013-en.

Pahl, J. (1983) 'The allocation of money and structuring of inequality within marriage', The Sociological Review, 31, 2, 237-62.

Pahl, J. (1989) Money and Marriage, Basingstoke: Macmillan.

Pahl, J. (1995) 'His money, her money: recent research on financial organisation in marriage', Journal of Economic Psychology, 16, 3, 361-76.

Pahl, J. (2005) 'Individualisation in couples finances: who pays for the children?', Social Policy and Society, 4, 4, 381-91.

Safilios-Rothschild, C. (1976) 'A macro- and micro-examination of family power and love: an exchange model', Journal of Marriage and the Family, 38, 2, 355-62.

Sainsbury, D. (1999) 'Gender and social-democratic welfare states', in D. Sainsbury (ed.), Gender and Welfare State Regimes, New York: Oxford University Press, pp. 76-98.

Schunck, R. (2013) 'Within and between estimates in random-effects models: advantages and drawbacks of correlated random effects and hybrid models', The Stata Journal, 13, 1, 65-76.

Singh, S. and Lindsay, J. (1996) 'Money in heterosexual relationships', Australian and New Zealand Journal of Sociology, 32, 3, 55-69.

Stocks, J., Díaz Martínez, C. and Halleröd, B. (2007) Modern Couples Sharing Money, Sharing Life, Basingstoke: Palgrave Macmillan.

Vogler, C. (1998) 'Money in households: some underlying issues of power', The Sociological Review, 46, 4, 687-713.

Vogler, C. (2005) 'Cohabiting couples: rethinking money in the household at the beginning of the twentyfirst century', The Sociological Review, 53, 1, 1-29. 
Vogler, C. (2009) 'Managing money in intimate relationships: similarities and differences between cohabiting and married couples', in J. Miles and R. Probert (eds.), Sharing Lives, Dividing Assets: An Inter-Disciplinary Study, Oxford: Portland, pp. 61-87.

Vogler, C. and Pahl, J. (1993) 'Social and economic change and the organisation of money within marriage', Work, Employment and Society, 7, 1, 71-95.

Vogler, C. and Pahl, J. (1994) 'Money, power and inequality within marriage', The Sociological Review, 42, 2, 263-88.

Vogler, C., Brockmann, M. and Wiggins, R. D. (2006) 'Intimate relationship and changing patterns of money management at the beginning of the twenty-first century', The British Journal of Sociology, $57,3,455-82$.

Vogler, C., Brockmann, M. and Wiggins, R. D. (2008) 'Managing money in new heterosexual forms of intimate relationships', The Journal of Socio-Economics, 37, 2, 552-76.

Zelizer, V. (1994) The Social Meaning of Money, Princeton, NJ: Princeton University Press.

Zelizer, V. (2005) The Purchase of Intimacy, Princeton, NJ: Princeton University Press. 